\title{
A személyi edzői hivatás tudományos és szakmai aspektusai
}

\section{Scientific and professional aspects of the personal trainer as a profession}

\author{
Szerző: $\quad$ Tánczos Zoltán ${ }^{\mathrm{a}, \mathrm{b}} \bowtie$ Bognár József ${ }^{\mathrm{c}}$ \\ a: Testnevelési Egyetem Doktori Iskola, Budapest, b: Testnevelési Egyetem Rekreáció Tanszék, \\ Budapest, c: Eszterházy Károly Egyetem, Sporttudományi Intézet, Eger
}

Beküldve: 2018. 12.12.

doi: $\quad$ 10.24365/ef.v60i1.395

\begin{abstract}
Összefoglaló: Az elmúlt évtizedben egyre több ember látogatja a fitnesztermeket és a wellnessközpontokat. A látogatók száma nemcsak számszerűen nő, hanem az életkor tekintetében is jóval szélesebb tartományt fog át, mint korábban. Míg a kétezres évek előtt elsősorban a lakosság fiatalabb és viszonylag szűk spektruma vette igénybe ezeket a sportolási lehetőségeket, mára a gyerekfitnesztől kezdve a funkcionális edzésen, aerobik- és aquafitnesz órákon és jógán keresztül a szenior tréningig lényegében a teljes népesség megtalálhatja a számára legmegfelelőbb mozgás- és kikapcsolódási formát az ilyen helyeken. Ezekben a sportközpontokban egyéni és csoportos mozgásformákkal egyaránt találkozunk, valamint a teljesen egyénre szabott edzések megtervezőjével, a személyi edzővel. A kézenfekvő megoldást keresők, és a leghatékonyabb edzések iránt érdeklődők elsősorban személyi edzőket vesznek igénybe, hogy szakszerú és biztonságos keretek között sportoljanak. A nemzetközi szakirodalom áttekintése alapján kijelenthetjük, hogy az elsődlegesen vizsgált szempontok: a személyi edző munkájának hatékonysága, a kliens egészségének megőrzése, a szakirányú képesítést adó intézmények - és így a végzettségek - sokfélesége, a szakmai szabályozás hiánya, az edző interperszonális kompetenciái, a nők felülreprezentáltsága és a túlsúlyos kliensekkel szembeni diszkrimináció. Célunk, hogy a fenti szempontok mentén ismertessük e dinamikusan fejlődő szakterület eddig elért prominens kutatási eredményeit. Mindezek a hazai témaspecifikus kutatások alapjául is szolgálhatnak, amelyek a hétköznapi emberek, a dolgozó lakosság egészségi mutatóit, fittségét, közérzetét kívánják előmozdítani.

Kulcsszavak: fitnesz; személyi edzés; személyi edző; prevenció; munkahelyi egészségfejlesztés
\end{abstract}

Summary: Over the past decade more and more people have been visiting fitness and wellness centres with the number of visitors not only numerically increasing, but also encompassing an age range that is much more extended than before. While the younger and relatively narrower spectrum of the population had already been intensively using these sports facilities before the 2000's, nowadays these establishments provide all kinds of physical and recreational activities for the whole population, ranging from kids' fitness to functional training and aerobics, water aerobics to yoga and senior training. In these centres we meet individual training opportunities, group classes as well as the personal trainer creating customized workout programs. Those clients looking for a smart solution and interested in an effective way of training will primarily use personal trainers to benefit from professional and safe workouts. Based on the overview of the international professional publication landscape we came to the conclusion that the main focus points examined are: effectiveness of the personal trainer, preservation of the client's health, diversity of institutions providing a great range of qualifications, lack of professional regulation, trainer's interpersonal competences, 
female over-representation and discrimination against overweight clients. With these aspects in mind, our aim was to recapitulate the most prominent research results of this dynamically developing field as they all can serve as a baseline for the relevant research in Hungary and finally, as a driver to promote health indicators, fitness and well-being of everyday people that are the working population.

Keywords: Fitness; Personal Training; Personal Trainer; Prevention; Workplace Health Promotion

\section{BEVEZETÉS}

A fitnesz- és személyi edzés a hazai szakirodalomban mindezidáig keveset vizsgált területnek számít. A személyi edzés célja, illetve az edzők edzésés munkamódszerei, valamint eszközrendszere jelentősen eltér a versenysportban alkalmazottaktól. A szabadidős és egészségfejlesztési céllal sportoló lakosság ilyen típusú edzése napjainkban virágkorát éli, a hétköznapi ember számára olyan megoldásokat kínál, amelyek hozzásegítik a jobb közérzet, a jobb munkabírás eléréséhez, az egészségi állapot hatékony fejlesztéséhez.

Egyre több adat támasztja alá azt a tényt, hogy a személyi edzéseken részt vevők fizikai és fittségi paraméterei, egészségi mutatói a rendszeres, tudatos és preventív személyre szabott edzésmunka hatására pozitív irányba változnak. ${ }^{1}$ Mindez kihat többek között az egyén közérzetére, munkavégző és stressztúrő képességére és közvetett módon a népegészségügyi kiadásokat is jelentősen csökkenti. Nem véletlen, hogy napjainkban a munkahelyi egészségfejlesztés keretein belül számos cég ad fitnesz- vagy uszodabérletet dolgozóinak, sőt, hazánkban is elindult az a folyamat, hogy a munkahely maga biztosít fitnesz- és egészségmegőrző programokat munkavállalói számára a munkavégzés helyszínén. A magyar lakosság egészségtudatos életvitelének, szokásrendszerének és fittségi mutatóinak alacsony szintje ismeretében érdemes áttekinteni e szakterület nemzetközi és hazai tudományos szakirodalmát. ${ }^{2}$ Célunk, hogy bemutassuk a személyi edzéssel kapcsolatos tényezőket és folyamatokat, továbbá, hogy mindezzel ösztönözzük a téma hazai kutatását. A továbbiakban a sporttudomány aspektusából a személyi edzői hivatás jellemző jegyei kerülnek bemutatásra, amelyhez több módszert használtunk kérdéseink megválaszolása érdekében. Egyfelől a széles körű dokumen- tumelemzést, valamint személyi edzőként és munkahelyi egészségfejlesztőként szerzett személyes tapasztalatainkra épülő reflektív önvizsgálatot végeztünk.

\section{A SZEMÉLYI EDZŐ TEVÉKENYSÉGI KÖRE}

A személyi edzés, mint a rekreáció fitnesz-irányzata az Egyesült Államokban jelent meg. A személyi edzők szolgáltatásait kezdetben jellemzően a társadalom prominens és tehetős tagjai vették igénybe, de nem kellett sokat várni arra, hogy a fitnesztermek világába is beszivárogva a középosztály számára is elérhetővé váljon. Különösen azok kérték e szolgáltatást előszeretettel, akik fittségi céljaik garantált és biztonságos elérése érdekében hatékony, szakszerű és személyre szóló edzéseken szerettek volna részt venni. A személyi edzés intézménye később Európába - így hazánkba - is eljutva egyre szélesebb körben terjedt el. Személyi edzésről beszélünk akkor, amikor a személyi edző kizárólag az adott tanítvánnyal dolgozik, így garantálva a maximális figyelmet és hatékonyságot (ez a legjellemzőbb foglalkozásforma), de létezik páros és csoportos edzésforma is. A személyi edző tanítványa szükségleteinek maximális figyelembevételével menedzseli és motiválja őt, kontrollálja a mozgássorok kivitelezését, és teljes körű életmódtanácsadást nyújt. Az egészséges életmód kialakításának érdekében a személyi edző figyelemmel kíséri más tudományterületek fejleményeit. Ezt az edző saját kompetenciahatárait átlépő támogató rendszert referenciahálózatnak nevezzük. [1. ábra] Fontos összetevő, hogy az edző személyes sportos megjelenésével, viselkedésével, egészségmagatartásával, sport- és fitnesz életmódjával nemcsak tanítványai, hanem a közvetlen környezete számára követendő példát mutat. A fitneszterembe érkező 
vendéget gyakran teljes életmódváltásra kell sarkallni mind a fizikai aktivitás, mind a táplálkozás, mind a pihenés tekintetében. ${ }^{3}$

A személyi edző legfőbb feladatai közé tartozik, hogy az első közös munka alkalmával felméri a fittségi állapotot, rögzíti a kliens adatait, javaslatot tesz esetleges orvosi kontrollra és a tanítvány figyelmébe ajánlja referenciahálózatát (például komolyabb ortopédiai jellegú elváltozások esetén gyógytornász, elhízás esetén pedig dietetikus bevonását javasolja). Az első foglalkozáson a tanítvánnyal közösen megállapodnak az edzés menetéről és rendjéről, amelyet adott esetben szerződésben is rögzíthetnek. A közös munka része a táplálkozási és komplett életmód-tanácsadás, valamint a személyre szabott edzésterv végrehajtása is. Az edzéseken folyamatos edzéskontroll, edzésdokumentálás, segítségadás és hibajavítás történik, jó hangulatú, motiváló környezetben.

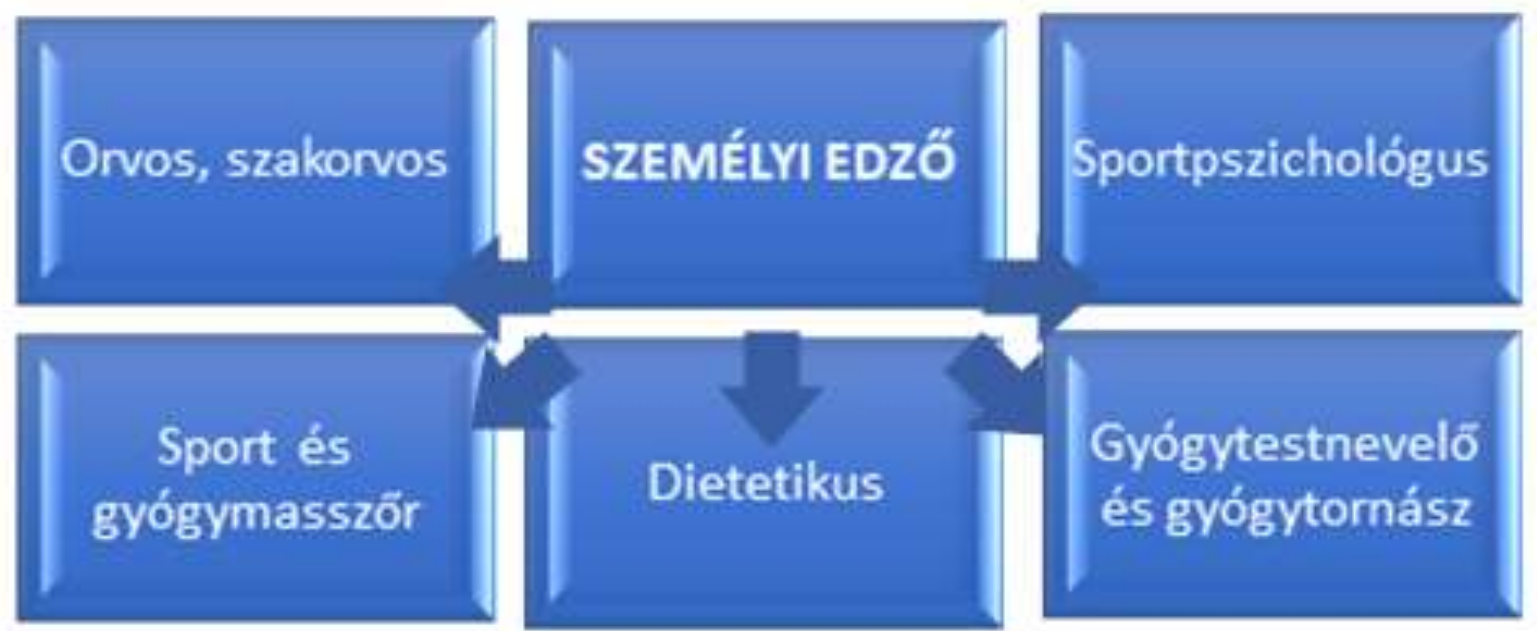

Forrás: saját szerkesztés

\section{SZAKIRÁNYÚ VÉGZETTSÉG ÉS SPORTSZAKMAI TAPASZTALAT}

Fontos, hogy a személyre szabott fitneszprogramok eredményesek és hatásosak legyenek, ennek mértéke pedig jelentősen függ az edző végzettségétôl és szakmai tapasztalatától. ${ }^{4}$ A fitneszipar nagyrészt szabályozatlan, hiányzik belőle az egységes ellenőrző testület és a szabályozó rendszer. Ebből kifolyólag különféle szintű és érvényességű képzések és végzettségek léteznek világszerte. A személyi edző tevékenységhez szükséges a sportszakmai végzettség megléte (hazánkban ez az OKJ 5581301 számú, emelt szintű szakképesítés-ráépülés, amely 240-360 órás), és a sportszakmai tapasztalat - vagy sportbéli jártasság -, amely a fitneszen túl más sportágakra is kiterjedhet. A legtöbb fitneszlétesítmény bármilyen oklevéllel felveszi az alkalmazottat, holott a színvonalas, gyakran költségesebb és időben hosszabb tanfolyamokon végzett edzők jóval képzettebbek társaiknál. Ez a helyzet Magyarországon sincsen másképp. Mivel azonban a fitneszipar alig szabályozott, a fitneszlétesítmények nem kötelesek olyan szakembert felvenni, aki rendelkezik megfelelő szakmai végzettséggel. Sőt, gyakran maguk a fitneszlétesítmények vezetői sem képesek különbséget tenni a különböző szintű oktatói és edzői végzettségek között. ${ }^{5}$ A személyi edzői hivatás megerősítésére egy egységesített, központi kontrollra lenne szükség.

\section{A SZEMÉLYI EDZŐ MUNKÁJÁNAK HATÉKONYSÁGA}

Napjainkban a fitnesztermekben és wellnessközpontokban számos egészségfejlesztő mozgásprogram van. Az edző az egyéni célok, a fizikai állapot és az életkor figyelembevételével személyre szabott programot állít össze. Egy 2014-es egyesült 
királyságbeli kutatás arról számolt be, hogy a személyi edzés 6 hónap alatt 36\%-os javulást eredményezett a fittségi paraméterek összességében. A tanulmány kiemelte, hogy a személyi edző szolgáltatását igénybe vevők sokkal jobb eredményt értek el a vizsgált paraméterekben, mint azok, akik nem éltek a lehetőséggel. ${ }^{6}$

Hasonlóan kedvező eredményekről számol be T. W. Storer 30 és 40 év közötti férfi alanyokkal végzett kutatásában, amelyben 3 hónap alatt, heti 3 edzéssel a vizsgált fizikai paraméterekben szignifikáns javulás mutatkozott a kontrollcsoporthoz képest. ${ }^{7}$ A fitnesztermek tagsági díja után a klubok számára a személyi edzésekből befolyó összeg hozza a legnagyobb bevételt. Meglepő módon mégis kevés kutatás foglalkozott a személyi- vagy fitneszedzővel végzett munka hatékonyságával.

Kennedy-Armbruster és mtsai megállapították, hogy a szakképzett személyi edzővel dolgozó kliensek esetében javult a $\mathrm{VO}_{2}$-érték és csökkentek az üló életmód káros hatásai az önállóan edző kontrollcsoporthoz képest. A képzett személyi edzővel végzett munka számos előnyei közé tartozik a teljesen személyre szabott edzésprogram, fokozott edzés közbeni motiváció és támogatás a fitnesz és egészségfejlesztési célok elérésében, az ütemezett edzéseknek köszönhetően kialakult következetesség és az állandó szakmai felügyelet. ${ }^{8}$

\section{A KLIENS EGÉSZSÉGÉNEK MEGŐRZÉSE}

A témával foglalkozó nemzetközi szakirodalmak és kutatások fontos megállapítása, hogy az edzések közben kimagaslóan fontos a tanítvány egészségének megőrzése és fejlesztése. Ehhez kiemelt jelentőségú a gerinc és az ízületek tudatos védelme, a tartó- és mozgatóapparátus átgondolt és teljes körű fejlesztése. Az edzések előtti alapos bemelegítés, az edzés közbeni mobilizációs és integrált specifikus gyakorlatok (pl. gerinc, vállízület-rotátorköpeny, csípő) és az edzés végén az egész testre kiterjedő változatos nyújtógyakorlatok szintén elengedhetetlenek. A személyi edzők által az edzéseken leggyakrabban tapasztalt sérülések a derékfájdalom (10,7\%), a vállízület-rotátor-köpeny szakadás/íngyulladás (8,9\%), a sípcsontfájdalom $(8,1 \%)$, a bokarándulás $(7,5 \%)$ és a gerinc elváltozásaiból létrejövő problémák $(7,4 \%)$ voltak. Nem meglepő, hogy a sérülések 90\%-a szabadsúlyokkal végzett edzéskor következett be. ${ }^{9}$

\section{AZ EDZŐVÁLASZTÁST BEFOLYÁSOLÓ SZEMPONTOK}

A sportszakmai végzettség és tapasztalat mellett a személyi edző munkáját egy harmadik tényező, az egyénre jellemző ún. interperszonális kompetencia is jelentősen befolyásolja. A tanítvánnyal való jó emberi kapcsolat kialakítása lényeges, hiszen a személyi edző szakmai sikere mellett anyagi szempontból is függ a vendégektől. A cikk szerzője megemlíti ennek olykor árnyoldalát is, hiszen a tanítványok gyakran aktuális személyes problémáikat is az edzővel osztják meg, amely leterhelheti a szakembert, érzelmi, mentális kimerüléshez, egyes esetekben akár depresszióhoz is vezethet. ${ }^{10}$

Az ügyfelek jellemzően olyan edzőt választanak, akiről feltételezik, hogy kellően empatikus, képes hatékonyan motiválni őket a kitúzött cél elérésében és abban, hogy véghezvigyék edzésprogramjukat. Emellett képes támogatni a fogyni, erősödni, fittségüket és egészségüket javítani vágyókat. A kutatás szerint az edző kiválasztásakor fontos szempont még az edző fizikuma is, sokan elsősorban a személyes szimpátia és a külsőségek alapján választanak maguknak személyi edzőt. ${ }^{11}$

Vannak olyan kiemelkedő szakmai színvonalat képviselő wellnessközpontok, ahol az edzők és oktatók internetes és helyi bemutatkozójában részletesen feltüntetik szakmai önéletrajzukat és szakirányú végzettségeiket. Ez segíthet a személyi edző hatékonyabb helyszíni kiválasztásában, de ami még ennél is fontosabb tényező az az, hogy az edző önállóan képes legyen saját magát hatékonyan értékesíteni a fitneszpiacon.

\section{A NŐK FELÜLREPREZENTÁLTSÁGA ÉS A TÚLSÚLYOS KLIENSEK DISZKRIMINÁLÁSA}

A nemzetközi kutatások két érdekes megállapítást is tesznek. Az egyik, hogy a nők jellemzően többségben vannak az edzőtermekben: 2005-ben a látogatók $57 \%$-a nő volt. ${ }^{12} \mathrm{Az}$ erre vonatkozó statisztikák szerint a nők a fitnesztermek és wellnessközpontok látogatói körében, de a fitnesziskolák képzéseinek 
résztvevői között is felülreprezentáltak, továbbá azt mutathatják, hogy a nők rendszerint elégedetlenebbek testükkel, mint a férfiak, jobban hisznek a személyi edző által nyújtott szolgáltatásokban, valamint képesek és készek a fejlődés érdekében időt, anyagiakat (stb.) áldozni.

A másik megállapítás, hogy a társadalom a túlsúlyos, különösen az elhízott embereket általában negatív diszkriminációval illeti, ami ront az önértékelésükön, és étkezési zavarokhoz, akár depresszióhoz is vezethet. Ez a csoport tart attól, hogy a fitnesztermekben és wellnessközpontokban is hasonló atrocitás éri őket, ezért gyakran félnek igénybe venni ezeket a helyszíneket és szolgáltatásokat. A személyi edzők hozzáállásában és munkavégzésében nem található különbség a vendégek testalkatával és fittségi állapotával kapcsolatosan. ${ }^{12}$ Az utóbbi időben Magyarországon is egyre több fitneszterem kínál egészségfejlesztő programokat a speciális célcsoportba tartozó vendégek (idősebb korosztály, kismamák, túlsúlyosok) számára is.

\section{ÖSSZEGZÉS}

A nemzetközi és a hazai szakirodalom áttekintése alapján arra a megállapításra jutottunk, hogy a nyugati társadalmakban évekkel ezelőtt felmerült problémák napjainkban, szinte közel azonos módon hazánkban is tetten érhetők. A személyi edzések ugyanakkor bizonyítottan jóval hatékonyabb és biztonságosabb lehetőséget kínálnak mindazok számára, akik a fittségi állapotukat és egészségüket fejleszteni szeretnék, ellentétben azokkal, akik az önállóan végzett, gyakran más vendégektől vagy az internetről ellesett jellemzően hibás technikák alkalmazásával edzenek. Ez utóbbi esetben az edzésmunka nem bizonyul hatékonynak, sőt a rossz technikákkal végrehajtott gyakorlatok súlyos egészségi kockázattal is járhatnak az egyénre nézve. Javasoljuk, ha van rá mód minden új fitneszterembe érkező vendég vegyen részt egy fittségi állapotfelmérésen és azt követő néhány alkalommal személyi edzésen is. Ezután a vendég dönthet arról, hogy folytatni kívánja-e a közös munkát az edzőjével, vagy önállóan végzi az edzéseit az adott klubban. Úgy véljük, amennyiben a bemutatkozó edzés sikeres volt, úgy a tanítvány az edzővel történő közös munka mellett dönt. A munkáltatók számára pedig javasoljuk azt, hogy minden esetben kérjék el az edzők szakmai végzettségét igazoló tanúsítványokat, és legyenek tisztában a különböző végzettségek közti olykor igen jelentős tudásbéli különbségekkel.

\section{HIVATKOZÁSOK}

\footnotetext{
${ }^{1}$ McClaran S.R. The effectiveness of personal training on changing attitudes towards physical activity. Journal of Sports Science and Medicine, 2003;2:10-14.

${ }^{2}$ Nemzeti Egészségfejlesztési Intézet Budapest, 2017.

${ }^{3}$ Tánczos Zoltán. Fitnesz és személyi edzés. Krea Fitt Kft., Budapest, 2018.

${ }^{4}$ Melton D., Katula J. A., Mustian K. The Current State of Personal Training: an Industry Perspective of Personal Trainers in a Small Southeast Community, in. Journal of Strength and Conditioning Research; 2008;22(3): 883-889. doi:10.1519/JSC.0b013e3181660dab

${ }^{5}$ Melton D., Dail T.K., Katula J.A. et al. The Current State of Personal Training: Managers' Perspectives, in. Journal of Strength and Conditioning Research, 2010;24(11)/3173-3179.

${ }^{6}$ McClaran S.R. Effectiveness Of Personal Training, in. International Journal Online of Sports Technology \& Human Engineering (IJOSTHE), 2014; Volume I, Issue IV.

${ }^{7}$ Storer T.W., Dolezal B.A., Berenc M.N. et al. Effect of Supervised, Periodized Exercise Training vs. Self-Directed Training on Lean Body Mass and Other Fitness Variables in Health Club Members, 2014. doi:10.1519/JSC.0000000000000331 ${ }^{8}$ Kennedy-Armbruster C., Shipley M., Yoke M. et al. Personal Training and Fitness Coaching: Do They Really Work? by [www] American Council on exercise, 2015.

${ }^{9}$ Waryasz G.R., Daniels A.H., Gil J.A. et al. Personal trainer demographics, current practice trends and common trainee injuries, in. Orthopaedic Reviews; 2016; volume 8:6600.
} 
${ }^{10}$ Ceren D. "It's More than Doing Sports Together, You Know. It's Deeply Personal": Preliminary Findings of an Ongoing Qualitative Study on the Relationships between Personal Fitness Trainers and Trainees, in. Open Journal of Social Sciences, 2017; 106-114. doi:10.4236/jss.2017.59008

${ }^{11}$ Melton D., Dail T.K., Katula J.A. et al. Women's Perspectives of Personal Trainers: A Qualitative Study, in. Sport J. $2011 ; 14(1)$.

${ }^{12}$ Fontana F., Bopes J., Bendixen S. et al. Discrimination against Obese Exercise Clients: An Experimental Study of Personal Trainers, in. International Journal of Exercise Science 2018;11(5): 116-128. 